JAR,Volume 2 Nomor 2 Agustus 2019 $p$ ISSN 2615-417X

\title{
KONSENTRASI DAN INTERVAL WAKTU APLIKASI POC POMI TERHADAP PERTUMBUHAN DAN PRODUKSI TANAMAN JAGUNG MANIS (Zea mays saccarata. L.)
}

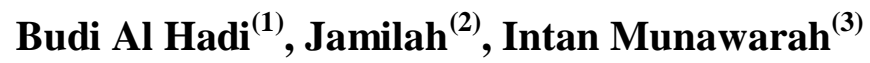 \\ ${ }^{1,2,3}$ Program Studi Agroteknologi Fakultas Pertanian Universitas Jabal Ghafur - Sigli \\ Email : budi_alhadi@yahoo.com,jamilah_unigha@yahoo.co.id
}

\begin{abstract}
ABSTRAK
Tujuan dari penelitian adalah untuk mengetahui pengaruh konsentrasi dan interval waktu pemberian pupuk cair POMI terhadap pertumbuhan dan produksi tanaman jagung manis. Penelitian dilaksanakan di kebun percobaan Fakultas Pertanian Universitas Jabal Ghafur Sigli, dari Januari sampai Maret 2017. Bahan yang digunakan adalah benih jagung manis varietas Bonanza F-1, pupuk organik cair POMI, pupuk NPK, air serta kelengkapan lain dalam menunjang penelitian. Penelitian ini menggunakan Rancangan Acak Kelompok pola faktorial. Ada 2 faktor yang diteliti yaitu faktor sistem konsentrasi (K) 3 taraf; $\mathrm{K}_{1}=2,5 \mathrm{ml} / \mathrm{liter}$ air/plot, $\mathrm{K}_{2}=5 \mathrm{ml} /$ liter air/plot, $\mathrm{K}_{3}=7,5 \mathrm{ml} /$ liter air/plot dan faktor interval waktu pemberian pupuk (I) 3 taraf; $\mathrm{I}_{1}=7 \mathrm{HST}, \mathrm{I}_{2}=22 \mathrm{HST}, \mathrm{I}_{3}=32 \mathrm{HST}$. Hasil penelitian menunjukkan, kosentrasi POMI berpengaruh sangat nyata terhadap parameter tinggi tanaman umur 32 HST dan panjang tongkol per sampel, berpengaruh nyata terhadap lebar daun umur 32 HST dan berat tongkol per plot, tidak berpengaruh nyata terhadap tinggi tanaman umur 7 HST dan 22 HST, lebar daun umur 7 HST dan 22 HST. Perlakuan terbaik dijumpai pada dosis pemberian 7,5 ml/liter $\left(\mathrm{K}_{3}\right)$. Interval POMI berpengaruh sangat nyata terhadap parameter tinggi tanaman umur $22 \mathrm{HST}$, berat tongkol per plot dan panjang tongkol per sampel serta berpengaruh nyata terhadap lebar daun umur 22 dan 32 HST. Perlakuan terbaik dijumpai pada $\left(\mathrm{I}_{2}\right)$ Interval POMI 22 HST.
\end{abstract}

Kata kunci: jagung, interval waktu, konsentrasi POMI

\section{PENDAHULUAN}

Jagung manis mempunyai peran strategis perekonomian nasional, mengingat fungsinya yang multiguna. Jagung dapat dimanfaatkan untuk pangan, pakan dan bahan baku industri. Jagung juga bisa dijadikan bioetanol seperti yang dilakukan di Amerika Serikat. Dari kalkulasi sederhana, jika asumsi bioetanol akan menggantikan $10 \%$ kebutuhan BBM dalam negeri yang mencapai 6 juta $\mathrm{x} \quad 2,4$ ton jagung ton jagung yang berarti 14,4 juta ton jagung atau setara dengan 3 juta hektar lahan tanaman jagung. Namun demikian bagi Indonesi kendala utama untuk memproduksi bioetanol dari jagung adalah bahan baku. Sejauh ini untuk memenuhi kebutuhan konsumsi jagung domestik, Indonesia masih mengimpor dari luar negri (Prihandana dan Hendroko, 2008).

Mengingat akan hal tersebut, perlu dilakukan usaha untuk membudidayakan jagung secara intensif dan komersial, sehingga kualitas, kuantitas dan kontinuitas produksinya pun dapat memenuhi standart permintaan konsumen (pasar). Caranya dapat dilakukan dalam berbagai bentuk, misalnya dengan meningkatkan penggunaan pupuk, melakukan pengaturan jarak tanam atau menggunakan berbagai macam zat pengatur tumbuh untuk mengatur petumbuhan dan produktivitas tanaman (Prabowo, 2007).

Pupuk organik cair mempunyai beberapa manfaat diantaranya dapat mendorong dan meningkatkan pembentukan klorofil daun dan pembentukan bintil akar pada tanaman leguminosa sehingga meningkatkan kemampuan fotosintesis tanaman dan menyerap nitrogen dari udara (Yusuf, 2010).

Semakin tinggi konsentrasi pupuk yang diberikan maka kandungan unsur hara yang diterima oleh tanaman akan semakin 
JAR,Volume 2 Nomor 2 Agustus 2019

$p$ ISSN 2615-417X

tinggi, begitu juga dengan semakin seringnya interval aplikasi pupuk POMI yang dilakukan pada tanaman, maka kandungan unsur hara juga semakin tinggi (Samekno, 2008).

Selain konsentrasi, peningkatan produksi jagung manis dapat pula dilakukan dengan cara perbedaan interval pemupukan yang berselang, yang merupakan salah satu tindakan yang sangat penting untuk menambah persediaan unsur hara, sehingga unsur hara yang dibutuhkan tersedia, diantaranya dengan interval pupuk POMI. Pemberian pupuk POMI bagi tanaman jagung berkaitan dengan jenis, konsentrasi, cara dan waktu pemupukan yang sesuai (Daniel, 2015).

\section{METODE PENELITIAN}

Penelitian dilaksanakan di kebun percobaan Fakultas Pertanian Universitas Jabal Ghafur Sigli, dari Januari sampai Maret 2017. Bahan yang digunakan adalah benih jagung manis varietas Bonanza F-1, pupuk organik cair POMI ,pupuk NPK, air serta alat kelengkapan lain dalam menunjang penelitian. Penelitian ini menggunakan Rancangan Acak Kelompok (RAK) pola faktorial. Ada 2 faktor yang diteliti yaitu faktor sistem konsentrasi (K) 3 taraf; $\mathrm{K}_{1}=2,5 \mathrm{ml} /$ liter air/plot, $\mathrm{K}_{2}=5 \mathrm{ml} /$ liter air/plot, $\mathrm{K}_{3}=7,5 \mathrm{ml} /$ liter air/plot dan faktor interval waktu pemberian pupuk (I) 3 taraf; $\mathrm{I}_{1}=7 \mathrm{HST}, \mathrm{I}_{2}=22 \mathrm{HST}, \mathrm{I}_{3}=32$ HST. Terdapat 9 kombinasi perlakuan dengan 3 ulangan, sehingga secara keseluruhan diperoleh 27 satuan percobaan.

\section{HASIL DAN PEMBAHASAN}

Konsentrasi Pemberian Pupuk Organik Cair POMI terhadap Pertumbuhan Tanaman.

\section{Tinggi Tanaman}

Pemberian pupuk cair POMI berpengaruh sangat nyata terhadap tinggi tanaman pada umur 32 HST, namun tidak berpengaruh nyata pada umur 7 dan 22 HST, dapat dilihat pada tabel 1 .
Tabel 1. Rata-rata Tinggi Jagung 7, 22 dan 32 HST akibat Kosentrasi Pupuk Organik Cair POMI

\begin{tabular}{|c|c|c|c|}
\hline \multirow{2}{*}{$\begin{array}{c}\text { Pengaruh } \\
\text { Penggunaan } \\
\text { Organik Cair } \\
\text { POMI }(\mathrm{K}) \\
\end{array}$} & \multicolumn{3}{|c|}{ Tinggi Tanaman $(\mathrm{cm})$} \\
\hline & $7 \mathrm{HST}$ & $22 \mathrm{HST}$ & $32 \mathrm{HST}$ \\
\hline $\mathrm{K}_{1}$ & 17,15 & 52,96 & $\begin{array}{c}145,15 \mathrm{a} \\
151,22\end{array}$ \\
\hline $\mathrm{K}_{2}$ & 19,09 & 52,93 & $a b$ \\
\hline $\mathrm{K}_{3}$ & \multicolumn{3}{|c|}{54,74} \\
\hline 0,05 & & \multicolumn{2}{|c|}{26,36} \\
\hline
\end{tabular}

Keterangan : Angka yang diikuti huruf yang sama pada kolom yang sama tidak berbeda nyata pada taraf $a=5 \%$ (Uji BNJ)

Semakin tinggi kosentrasi POMI yang diberikan, maka semakin baik pula pertumbuhan tanaman jagung. Pupuk sebagai penyuplai hara $\mathrm{N}, \mathrm{P}$ dan $\mathrm{K}$ pada tanaman jagung karena dapat menguatkan serapan hara yang ditujukan kedalam pembentukan pertumbuhan vegetatif tanaman.

Pertumbuhan tinggi tanaman jagung sangat dipengaruhi oleh unsur $\mathrm{N}$ yang terkandung pada pupuk POMI. Lingga (1998) menyatakan bahwa, peranan nitrogen penting dalam mendorong pertumbuhan vegetatif tanaman. Tersedianya Nitrogen yang cukup menyebabkan adanya keseimbangan rasio antara daun dan akar, maka pertumbuhan vegetatif berjalan dengan sempurna. Pada kondisi demikian akan berpengaruh pada tanaman untuk memasuki fase pertumbuhan generatif.

\section{Lebar Daun Tanaman}

Pemberian pupuk organik cair POMI berpengaruh nyata terhadap lebar daun tanaman pada umur 32 HST, namun tidak berpengaruh nyata pada umur 7 dan 22 HST, dapat dilihat pada tabel 2.

Tabel 2. Rata-rata Lebar Daun Jagung manis 7, 22 dan 32 HST Akibat Kosentrasi Pemberian Pupuk Organik Cair POMI 
JAR, Volume 2 Nomor 2 Agustus 2019

\begin{tabular}{cccc}
\hline \hline Pengaruh & \multicolumn{3}{c}{ Lebar Daun Tanaman $(\mathrm{cm})$} \\
$\begin{array}{c}\text { Pengunaan } \\
\text { Organik Cair } \\
\text { POMI (K) }\end{array}$ & 7 HST & $22 \mathrm{HST}$ & $32 \mathrm{HST}$ \\
\hline $\mathrm{K}_{1}$ & 1,78 & 4,49 & $10,30 \mathrm{a}$ \\
$\mathrm{K}_{2}$ & 1,81 & 4,39 & $10,16 \mathrm{ab}$ \\
$\mathrm{K}_{3}$ & 1,87 & 4,65 & $11,29 \mathrm{~b}$ \\
\hline BNJ 0,05 & - & & 1,17
\end{tabular}

Keterangan : Angka yang diikuti huruf yang sama pada kolom yang sama tidak berbeda nyata pada taraf $a=5 \%$ (Uji $\mathrm{BNJ}$ )

Kandungan unsur hara yang terdapat pada pupuk organik cair POMI pada umur 32 HST dapat diserap sempurna oleh tanaman jagung. Menurut Lutfi (2007) penggunaan pupuk melalui daun memang memiliki tingkat efisiensi yang tinggi. Proses pemasukan unsur hara melalui daun terjadi karena difusi dan osmosis melalui lubang stomata. Selain itu konsentrasi yang hanya berpengaruh pada umur 32 HST diduga saat itu tanaman membutuhkan unsur hara untuk pembentukan daun. Menurut Masudal (2004) pemupukan lewat daun memungkinkan tersedianya unsur hara bagi tanaman pada saat kebutuhan tanaman lebih besar dari penyerapannya, terutama saat suplai unsur hara dari tanah sudah berkurang.

\section{Berat Tongkol Per Plot}

Pemberian pupuk organik cair POMI berpengaruh nyata terhadap berat tongkol per plot tanaman jagung manis, dapat dilihat pada tabel 3 .

Tabel 3.Rata-rata Berat Tongkol per plot Tanaman Jagung Manis 70 HST akibat Konsentrasi Pemberian Pupuk Organik Cair POMI

Pengaruh
Pengunaan
Organik Cair

\begin{tabular}{cc}
\hline POMI & ISSN 2615-417X \\
\hline $\mathrm{K}_{1}$ & $4,47 \mathrm{a}$ \\
$\mathrm{K}_{2}$ & $5,04 \mathrm{ab}$ \\
$\mathrm{K}_{3}$ & $5,50 \mathrm{~b}$ \\
\hline BNJ 0,05 & 0,82
\end{tabular}

Keterangan : Angka yang diikuti huruf yang sama pada kolom yang sama tidak berbeda nyata pada taraf $a=5 \%$ (Uji $\mathrm{BNJ})$

Perlakuan pupuk organik cair POMI berpengaruh nyata terhadap berat tongkol, hal ini sesuai dengan fungsi unsur hara yang terkandung dalam pupuk organik cair POMI terhadap proses pertumbuhan generatif, yaitu dalam proses pembentukan primordia bunga dan buah. Pospor yang disumbangkan oleh pupuk organik cair POMI sangat berperan dalam pertumbuhan fase generatif tanaman jagung, selain hara nitrogen dan hara kalium.

Menurut Fachruddin dan Idham (2004), pupuk organik dapat memperbaiki struktur tanah sehingga meningkatkan perkembangan akar, dengan demikian meningkatkan serapan unsur hara tanaman dan menekan fiksasi $\mathrm{P}$ oleh $\mathrm{Al}$ sehingga ketersediaan unsur $\mathrm{P}$ bagi tanaman dapat terpenuhi. Berimbangnya antara pertumbuhan vegetatif dan generatif pada awal fase generatif dapat memperbaiki organ reproduktif secara keseluruhan.

\section{Panjang Tongkol}

Pemberian pupuk organik cair POMI berpengaruh sangat nyata terhadap panjang tongkol per sampel, dapat dilihat pada Tabel 4.

Tabel 4. Rata-rata Panjang Tongkol Per Sampel Tanaman Jagung manis 70 HST Akibat Konsentrasi Pemberian Pupuk Organik Cair POMI

\begin{tabular}{cc}
\hline \hline Konsentrasi & Panjang Tongkol Per Sampel \\
Pemberian Pupuk & $(\mathrm{cm})$ \\
\hline
\end{tabular}


$\operatorname{POMI}(\mathrm{K})$

\begin{tabular}{cc}
\hline $\mathrm{K}_{1}$ & $20,48 \mathrm{a}$ \\
$\mathrm{K}_{2}$ & $22,19 \mathrm{~b}$ \\
$\mathrm{~K}_{3}$ & $23,00 \mathrm{~b}$ \\
\hline BNJ 0,05 & 1,30 \\
\hline
\end{tabular}

Keterangan: Angka yang diikuti huruf yang sama pada kolom yang sama tidak berbeda nyata pada taraf $a=5 \%(U j i$ $\mathrm{BNJ}$ )

Tabel 4 dapat dilihat bahwa, pada umur $70 \mathrm{HST}$ rata-rata berat tongkol per plot tanaman jagung terpanjang dijumpai pada perlakuan $\mathrm{K}_{3}$ dengan dosis $(7,5 \mathrm{ml} /$ liter air), dengan nilai $23,00 \mathrm{~cm}$, yang tidak berbeda nyata dengan perlakuan $\mathrm{K}_{2}$ dengan dosis $(5 \mathrm{ml} /$ liter air) namun berbeda nyata dengan perlakuan $\mathrm{K}_{1}$ dengan dosis $(2,5 \mathrm{ml} /$ liter air). Sedangkan panjang tongkol tanaman terpendek dijumpai pada perlakuan $\mathrm{K}_{1}$ dengan dosis (2,5 ml/liter air), dengan nilai $20,48 \mathrm{~cm}$ yang berbeda nyata dengan perlakuan $\mathrm{K}_{3}$ dengan dosis $(7,5 \mathrm{ml} /$ liter air), dan $\mathrm{K}_{2}$ dengan dosis (7,5 ml/ liter air).

Hal ini disebabkan unsur hara makro dan mikro pada pupuk POMI dapat diserap dengan efektif oleh tanaman jagung. Sesuai dengan pendapat Atmojo (2003), penambahan bahan organik kedalam tanah akan menambahkan unsur hara baik makro maupun mikro yang dibutuhkan oleh tanaman, sehingga efisiensi nutrisi tanaman dapat meningkatkan produksi tanaman.

\section{Analisis Interval Pemberian Pupuk Organik Cair POMI terhadap Pertumbuhan Tanaman \\ Tinggi Tanaman}

Interval pemberian pupuk organik cair POMI berpengaruh sangat nyata terhadap tinggi tanaman pada umur 22 HST, namun tidak berpengaruh nyata pada umur 7 dan 32 HST, dapat dilihat pada tabel 5.
Tabel 5. Rata-rata Tinggi Jagung Manis 7, 22 dan 32 HST Akibat Interval Pemberian Pupuk Organik Cair POMI

\begin{tabular}{cccc}
\hline \hline $\begin{array}{c}\text { Pupuk Interval } \\
\text { Pemberian } \\
\text { Pupuk } \\
\text { POMI(I) }\end{array}$ & \multicolumn{3}{c}{ Tinggi Tanaman (cm) } \\
\cline { 2 - 4 } & 7 HST & $22 \mathrm{HST}$ & $32 \mathrm{HST}$ \\
\hline $\mathrm{I}_{1}$ & 17,96 & $53,56 \mathrm{ab}$ & 158,15 \\
$\mathrm{I}_{2}$ & 19,26 & $60,15 \mathrm{~b}$ & 161,78 \\
$\mathrm{I}_{3}$ & 16,26 & $46,93 \mathrm{a}$ & 155,63 \\
\hline BNJ 0,05 & - & 9,24 & - \\
\hline
\end{tabular}

Keterangan: Angka yang diikuti huruf yang sama pada kolom yang sama tidak berbeda nyata pada taraf $\mathrm{a}=5 \%(\mathrm{Uji}$ $\mathrm{BNJ}$ )

Hasil analisi ragam menyatakan interval waktu penyemprotan pupuk organik cair POMI berpengaruh nyata terhadap tinggi tanaman pada umur 22 HST. Hal ini diduga ketepatan waktu aplikasi dan unsur hara yang terdapat pada pupuk organik cair POMI yang diberikan pada umur 15 HST dapat diserap oleh tanaman dengan sempurna, sehingga dapat merangsang pertumbuhan tinggi tanaman. Menurut Maidin (2002) pengaruh tingginya curah hujan dan ketepatan waktu aplikasi pemupukan dapat merangsang pertumbuhan vegetatif tanaman.

\section{Lebar Daun Tanaman}

Interval pemberian pupuk cair POMI berpengaruh nyata terhadap lebar daun tanaman pada umur 22 dan 32 HST, namun tidak berpengaruh nyata pada umur 7 HST, dilihat pada tabel 6 .

Tabel 6. Rata-rata Lebar Daun Jagung Manis 7, 22 dan 32 HST Akibat Perbedaan Interval Pupuk Organik Cair POMI

\begin{tabular}{cccc}
\hline \hline Pengaruh & \multicolumn{2}{c}{ Lebar Daun Tanaman $(\mathrm{cm})$} \\
Pengunaan & & & \\
Organik Cair & 7 HST & 22 HST &
\end{tabular}




\begin{tabular}{cccc}
\hline POMI (I) & & & HST \\
\hline $\mathrm{I}_{1}$ & 1,78 & $4,58 \mathrm{ab}$ & $9,95 \mathrm{a}$ \\
& & & 10,54 \\
$\mathrm{I}_{2}$ & 2,00 & $5,00 \mathrm{~b}$ & $\mathrm{ab}$ \\
$\mathrm{I}_{3}$ & 1,69 & $3,95 \mathrm{a}$ & $11,26 \mathrm{~b}$ \\
\hline BNJ 0,05 & - & $\mathbf{0 , 9 6}$ & $\mathbf{1 , 1 7}$
\end{tabular}

Keterangan: Angka yang diikuti huruf yang sama pada kolom yang sama tidak berbeda nyata pada taraf $a=5 \%(\mathrm{Uji}$ $\mathrm{BNJ})$

Interval waktu aplikasi pupuk organik cair POMI 7 HST tidak efektif karena pengaruh tinggi curah hujan yang terjadi. Sehingga unsur $\mathrm{N}$ yang terkandung dalam pupuk POMI tidak dapat diserap oleh tanaman dan mengakibatkan lebar daun terhambat. Menurut Fransiscus (2006) menyatakan, pengaplikasian pupuk organik pada waktu yang tepat dapat memperbaiki keasaman pada tanah masam. Permasalahan yang ada pada tanah masam adalah besarnya jumlah unsur hara mikro yang bisa meracuni tanaman. Peran pupuk organik sebagai pembenah tanah bisa berfungsi untuk mengikat sebagian unsur-unsur beracun tersebut sehingga tanaman akan tetap tumbuh sehat.

\section{Berat Tongkol Per Plot}

Interval pemberian pupuk cair POMI berpengaruh sangat nyata terhadap berat tongkol Per Plot, dapat dilihat pada tabel 7.

Tabel 7. Rata-rata Berat Tongkol Per Plot Tanaman Jagung Manis 70 HST Akibat Interval Pemberian Pupuk Organik Cair POMI

\begin{tabular}{cc}
\hline \hline $\begin{array}{c}\text { Pupuk Interval } \\
\text { Pemberian Pupuk } \\
\text { POMI(I) }\end{array}$ & Berat Tongkol Per Plot (Kg) \\
\hline $\mathrm{I}_{1}$ & $4,19 \mathrm{a}$
\end{tabular}

\begin{tabular}{cc}
$\mathrm{I}_{2}$ & $5,04 \mathrm{ab}$ \\
$\mathrm{I}_{3}$ & $5,78 \mathrm{~b}$ \\
\hline BNJ 0,05 & 0,82 \\
\hline
\end{tabular}

Keterangan : Angka yang diikuti huruf yang sama pada kolom yang sama tidak berbeda nyata pada taraf $a=5 \%(\mathrm{Uji}$ $\mathrm{BNJ}$ )

Hasil analisis ragam berat tongkol tertinggi dijumpai pada interval pemberian pupuk organik cair POMI umur $32 \mathrm{HST}\left(\mathrm{I}_{3}\right)$, hal ini dikarenakan interval pemberian pupuk organik cair POMI pada masa generativ dapat tersedia unsur hara bagi pembentukan buah jagung. Seperti yang dikatakan Rinsema (1993) bahwa, untuk mendapatkan hasil yang tinggi dan kualitas yang baik, maka syarat utama adalah tanaman harus mendapat unsur hara yang cukup selama masa pembungaan sampai masa pembentukan buah. Waktu pemberian pupuk organik yang tepat sangat berguna untuk memenuhi kebutuhan unsur hara baik makro maupun mikro bagi tanaman jagung dan tanaman palawija lainya.

\section{Panjang Tongkol}

Interval pemberian pupuk organik cair POMI berpengaruh sangat nyata terhadap panjang tongkol per sampel, dapat dilihat pada tabel 8 .

Tabel 8. Rata-rata Panjang Tongkol Per Sampel Tanaman Jagung Manis 70 HST Akibat Interval Pemberian Pupuk Organik Cair POMI

\begin{tabular}{cc}
\hline $\begin{array}{c}\text { Pupuk Interval } \\
\text { Pemberian } \\
\text { Pupuk POMI(I) }\end{array}$ & $\begin{array}{c}\text { Panjang Tongkol Per Sampel } \\
(\mathrm{cm})\end{array}$ \\
\hline $\mathrm{I}_{1}$ & $21,15 \mathrm{a}$ \\
$\mathrm{I}_{2}$ & $21,56 \mathrm{ab}$ \\
$\mathrm{I}_{3}$ & $22,96 \mathrm{~b}$ \\
\hline BNJ 0,05 & 1,30 \\
\hline \hline
\end{tabular}


Keterangan: Angka yang diikuti huruf yang sama pada kolom yang sama tidak berbeda nyata pada taraf $a=5 \%$ (Uji $\mathrm{BNJ}$ )

Tabel 8 dapat dilihat bahwa, pada umur 70 HST rata-rata panjang tongkol per sampel tanaman jagung manis tertinggi dijumpai pada perlakuan $\mathrm{I}_{3} \quad(32$ HST) dengan nilai $22,96 \mathrm{~cm}$ berbeda nyata dengan perlakuan $I_{1}$ (2 HST) dan tidak berbeda nyata dengan $\mathrm{I}_{2}$ (22 HST). Sedangkan tanaman terendah dijumpai pada perlakuan $\mathrm{I}_{1}$ (7 HST), dengan nilai 21,15 $\mathrm{cm}$, yang tidak berbeda nyata dengan perlakuan $\mathrm{I}_{2}$ (22 HST) dan berbeda nyata dengan $\mathrm{I}_{3}$ (32 HST).

Hasil analisis ragam menunjukkan panjang tongkol tertinggi dijumpai pada interval pemberian pupuk organik cair POMI umur $32 \mathrm{HST}$, hal ini disebabkan pupuk organik cair POMI mengandung Unsur hara makro dan mikro yang maksimal. Seperti yang dikemukakan oleh ( Daniel, 2015). Pupuk organik cair POMI mengandung $\mathrm{N}$ Total 5,09\%, $\mathrm{P}_{2} \mathrm{O}_{5} 4,30 \%$, $\mathrm{K}_{2} \mathrm{O} 5,46 \%$ Mengandung Unsur hara mikro yang tepat : Fe 410 ppm, Mn 737 ppm, Cu 440 ppm, Zn 354 ppm, B 260 ppm, Co 12 ppm, Mo 3 ppm, Mengandung hormon pertumbuhan Mengandung C Organik : $28,53 \%$ Pupuk organik cair POMI memiliki $\mathrm{pH} 4,55$ Yang sangat penting pupuk organik POMI juga mengandung berbagai mikroorganisme (agensia hayati) yang sangat menguntungkan tanaman Azospirillium sp 8,0 x $10^{8} \quad$ CFU/ gr, Azotobacter sp 9,6 × $10^{8}$ CFU/ gr, Pseudomonas sp 5,9 $\times 10^{8} \mathrm{CFU} / \mathrm{gr}$, Bacillus sp 2,8 $810^{8} \mathrm{CFU} /$ gr, Aspergillus sp $2,2 \mathrm{x}$ $10^{7}$ propagul/

gr.

Ketersediaan $\mathrm{N}$ merupakan faktor dominan yang menentukan laju berbagai proses pertumbuhan vegetatif, sedangkan unsur $\mathrm{P}$ berperan berperan mempengaruhi pematangan dan pembentukan biji bernas ( Masudal, 2004).

\section{KESIMPULAN DAN SARAN}

Kosentrasi POMI berpengaruh sangat nyata terhadap parameter tinggi tanaman umur 32 HST dan panjang tongkol per sampel. Berpengaruh nyata terhadap lebar daun umur 32 HST dan berat tongkol per plot, namun tidak berpengaruh nyata terhadap tinggi tanaman umur 7 HST dan 22 HST, lebar daun umur 7 HST dan 22 HST, perlakuan terbaik dijumpai pada dosis pemberian 7,5 $\mathrm{ml} /$ liter $\left(\mathrm{K}_{3}\right)$.

Interval POMI berpengaruh sangat nyata terhadap parameter tinggi tanaman umur 22 HST, berat tongkol per plot dan panjang tongkol per sampel serta berpengaruh nyata terhadap lebar daun umur 22 dan 32 HST. pada pengamatan yang lain tidak berpengaruh nyata, perlakuan terbaik dijumpai pada $\left(\mathrm{I}_{2}\right)$ Interval POMI 22 HST yang tidak berbeda nyata dengan $\left(\mathrm{I}_{3}\right)$

\section{DAFTAR PUSTAKA}

Atmojo , S. W. 2003. Penerapan Bahan Organik Terhadap Kesuburan Tanah dan Upaya Pengelolaannya. Fakultas Pertanian, UNS. Surakarta.

Daniel Prasetyo, 2015. Aplikasi Dan Hasil Penggunaan Pupuk Organik POMIdiujicoba oleh kementrian pertanian untuk skala nasionalhttp://www.acidatama.co.id/ index.php.

Fachrudin, dan Idham 2004. Pengaruh Residu Penggunaan Bahan Organik, Dolomit dan $\mathrm{KCl}$ terhadap Pertumbuhan Tanaman Kacang Tanah (Arachis hypogeae. L.) pada Oxic .

Fransiscus. 2006. Pemberian Beberapa Pupuk Organik Terhadap Pertumbuhan dan Produksi Kacang Tanah (Archis hipogaea L). Skripsi Universitas Riau. Pekanbaru, tidak dipublikasikan.

Lingga. 1998. Petunjuk Penggunaan Pupuk. Penebar Swadaya. Jakarta 161 Halaman. 
Lutfi, M. A. 2007. Pengaruh Pemberian Beberapa Jenis Pupuk Daun Terhadap Kadar N dan K Total Daun serta Produksi Tanaman Cabai Besar (Capsicum annum L) pada Inceptisol Karang Ploso, Malang. Skripsi. Jurusan Tanah. Fakultas Pertanian. Universitas Brawijaya.

Maidin, N. B. 2002. Pengaruh Dosis dan Waktu Aplikasi Pupuk Cair Pada Tanaman Kedelai ((Glycine $\max \mathrm{L})$. Skripsi. Jurusan Budidaya Pertanian. Fakultas Pertanian. Institut Pertanian Bogor.

Prabowo, A. Y., 2007. Teknis Budidaya : Budidaya Jagung. http://teknisbudidaya.blogspot.com/2007/10/budi dayajagung.html/07/04/2011

Prihandana, R., dan Hendroko, R., 2008. Energi Hijau Pilihan Bijak Menuju Negeri Mandiri Energi. Penebar Swadaya. Bogor.

Rinsema, W. T. 1993. Bermestingen meststoffen, Terjemahan H. M. Saleh. Bhratara Niaga Media, Jakarta.

Sumekno R, 2008. Pemupukan.PT. Citra AjiParama Yogyakarta.Penerbit KANISIUS. Yogyakarta

Yusuf,T. 2010. Pemupukan dan Penyemprotan Lewat Daun. Tohari Yusuf' $\mathrm{s}$

Pertanian

Blog.http://tohariyusuf.wordpress.com / 